2. Лью-Роорд Й. ван дер. EUROCLIO - 10 років роботи над вивченням і викладанням історії [Електроннй $\quad$ ресурс] / Йоке ван дер Лью-Роорд. - Режим доступу: http://www.novadoba.org.ua/ukr/node/54 3. Страдлінг Р. Проблеми викладання історії у XXI столітті [Електроннй ресурс]/ P. Страдлінг. - Режим доступу: http://www.novadoba.org.ua/ukr/node/53

УДК 37.(091)

Олена Устименко-Косоріч

\title{
ТИПИ БАЯННО-АКОРДЕОННОЇ ШКОЛИ В СИСТЕМІ МУЗИЧНОЇ ОСВІТИ СЕРБІї
}

\begin{abstract}
Устименко-Косоріч О. А. Типи баянно-акордеонної школи в системі музичної освіти Сербіï.

У статті проаналізовано типи сербської баянно-акордеонної школи в контексті жанрової парадигми як складників потужної системи національної музичної освіти, яка функціонує на базі дворівневої програми - виховання компетентного фахівця суспільнонаціонального призначення (аматора) та потенційного виконавця «Високого мистецтва» засобами «узагальнення через жанр».

Ключові слова: жанрово-типологічна система музичної освіти, баянно-акордеонна
\end{abstract} школа, народна музика, класифікація, традиція, теорія.

Устименко-Косорич Е. А. Типы баянно-акордеонной школы в системе музыкального образования Сербии.

В статье проанализированы типы сербской баянно-аккордеонной школы в контексте жанровой парадигмы как составляющих элементов мощной системы национального музыкального образования, которое функционирует на базе двухуровневой программы воспитание компетентного специалиста общественно-национального назначения (любителя) и потенциального исполнителя «Высокого искусства» средствами «обобщение через жанр».

Ключевые слова: жанрово-типологическая система музыкального образования, баянно-аккордеонная школа, народная музыка, классификация, традиция, теория.

Ustymenko-Kosorich E. A. Types of accordion schools in the system of music education in Serbia.

The article analyzes the types of accordion school in Serbia in the context of genre paradigm as part of a strong national music education system. This system is functioning on the basis of a two-level programs: education of a competent specialist for social and national purposes (amateur) and a performing musician of «High Art» by means of «generalization by genre».

Key words: genre and typological system, accordion school, folk music, classification, tradition, theory.

На початку XX століття (1920р.) - у період зародження сербської баянно-акордеонної школи пріоритетним завданням музичної освіти було музичне просвітництво, залучення широкого суспільного загалу до музичного мистецтва. Але вже тоді виникали ідеї до створення відповідних навчальних закладів, які би відповідали індивідуальним потребам у підвищенні професійного виконавського рівня. У цьому сенсі в Сербії здійснюються спроби організації диференційованого виховання за ознаками підготовки майбутнього любителя або 
фахівця певної музичної справи. Сербська музична освіта, переважно виконавська, пройшла довгий та складний шлях у формуванні таких закладів - драматичні історичні події, відсутність фахівців у державі гальмували розгортання динаміки розвитку музичної професійної освіти, тому баянно-акордеонне мистецтво до 1960-х років зберігало народний, стихійних характер.

У контексті історії розвитку сербського баянно-акордеонного мистецтва чітко відокремились форми музикування за жанровою підпорядкованістю, які донині не втрачають своєї актуальності завдяки наявності різних типів фахових навчальних закладів виконавських шкіл. Мова йде про репертуарні настанови музично-освітніх закладів, за якими умовно формувався певний тип навчального закладу- народний, загальномасовий, культурно-просвітницький, естрадно-популярний, академічний.

Сучасна музична педагогіка до сьогодні не має досконалої типологічної системи музичної освіти з урахуванням жанрової систематизації. Потреба в розробленні відповідної теорії назріла у зв'язку з ускладненням і поширенням сербської баянно-акордеонної інфраструктури, формуванням мережі освітніх закладів за певним жанрово-музичним типом. Відповідно до жанрової підпорядкованості навчальних музичних закладів змінюються технології викладання, соціокультурний статус музично-освітніх установ, які потребують наукового аналізу та визначення цього явища в контексті сучасної музичної педагогіки.

Різні жанрові типології представлені в теоріях жанру, викладених у працях М. Арановського, Б. Асаф'єва, Г. Бесселера, О. Соколова, А. Сохора та ін. Найбільш поширені типології музичних жанрів передбачають їх систематизацію за засобом виконання - вокальні, інструментальні, вокально-інструментальні (Г. Бесселер); за призначенням - побутові та призначені «для слухання» (Ю. Юцевич); за масштабом - великі та камерні (М. Арановський); за змістом - ліричні, драматичні, епічні, комічні (М. Каган); за умовами виконання - театральні, концертні, кіномузика (А. Сохор), проте наукових досліджень, в яких була б запропонована типологія музичних закладів з урахуванням їх жанрової підпорядкованості, обмаль.

Отже, мета статmi - визначення жанрово-типологічної системи сербської баянноакордеонної освіти.

У контексті дослідження сербську баянно-акордеонну школу розглядаємо як поліцентричне музично-освітне явище, типи якої вирізняються рівнем фахової компетентності педагогів, організацією навчально-виховного процесу, соціальним статусом, формами власності, напрямами підготовки баяністів-акордеоністів, жанровою спрямованістю. Доцільність національно-типологічного проекту дослідження зумовлена: відсутністю аналізу сербської баянно-акордеонної галузі як складно-структурованої системи, визначення ï елементів (типів), зв'язків між ними, виявлення зовнішніх чинників, які впливають на динаміку розвитку системи та їі елементів (типів).

На основі вивчення галузевої літератури встановлено, що найбільш відповідною в реалізації національно-типологічного проекту є система музичних жанрів О. Соколова, що базується на класифікації музичних явищ за такими ознаками: сфера побутування, соціальний статус, період існування, види та напрями музичної діяльності, які обрано основними критеріями типологізації сербської баянно-акордеонної школи.

Аналіз структури сербської баянно-акордеонної школи як системи дозволив виокремити ii типи й згрупувати їх за напрямами: народні: народно-національний, самодіяльний, масовий, естрадний; професійні: академічний, академічно-народний.

Народно-національний тип школи виник у 1920-х роках ХХ століття й нині 
характеризується як баянно-акордеонна школа народної музики. Аналіз довідковоенциклопедичної літератури показав, що в термінологічній базі це поняття залишається не визначеним, що надало підстави для власного його тлумачення. Поняття «сербська баянноакордеонна школа народної музики» ми розуміємо так: це мережа недержавних музичноосвітніх установ альтернативного характеру, діяльність яких спрямована на підготовку баяністів-акордеоністів етнокультурного призначення. Доведено, що сербська баянноакордеонна школа народної музики - це музично-освітня галузь локального (національного) призначення, яка функціонує та розвивається під впливом соціокультурних тенденцій певної країни та $є$ унікальним музично-освітнім явищем у межах світового музично-освітнього простору.

Народно-національний тип сербської баянно-акордеонної школи виник у колах музикантів-аматорів, творчість яких заснована на традиційних формах музикування (за О. Соколовим, чисті музичні жанри [3]). Запропоновано народно-національний тип розглядати як первісну творчо-виконавську базу музично-освітнього характеру, зміст якої полягає у просвітницькій діяльності баяністів-акордеоністів, заснованої на традиційних формах музикування.

Самодіяльний тип сербської баянно-акордеонної школи виник у 1940-х роках XX століття в колах музикантів-аматорів, проте в його межах формувалися виконавські прийоми, види техніки, виникали організовані форми творчої діяльності - творчі спілки баяністів-акордеоністів, поширювався музичний репертуар та музично-виконавські напрями - пісенно-побутові й танцювально-побутові (за О. Соколовим, взаємодіючий жанр як синтез слова-музики-танцю [3]). Саме в межах самодіяльного типу відбувся розподіл творчої діяльності баяністів-акордеоністів - соліст (концертний виконавець) та акомпаніатор (концертмейстер), які нині входять до класифікатора професій баяністів-акордеоністів.

Масовий тип сербської баянно-акордеонної школи виник у 1950-х роках ХХ століття та позначений стихійним відкриттям баянно-акордеонних секцій у клубах культури i дозвілля, загальноосвітніх закладах, приватних баянно-акордеонних школах народної музики. У межах масового типу сербської баянно-акордеонної школи були сформовані форми організації навчально-виховного процесу та педагогічні принципи підготовки баяністів-акордеоністів за народним напрямом, а саме: відсутність оцінювання успішності учнів та атестата державного зразка; вільний термін навчання; відсутність розподілу за класами і групами та обов'язкових програмних вимог; вільний вибір навчально-виховного процесу учнем: від індивідуальних до колективних форм підготовки; особлива увага до розвитку артистичних здібностей засобами активізації концертної діяльності; усна передача музичного матеріалу від майстра до послідовника; опанування творами народної музики переважно балканських країн.

Eстрадний тип - виник у 1990-х років ХХ століття та характеризується: уведенням у виконавську практику баяністів-акордеоністів електроприладів та акустичних систем; популяризацією колективних форм музикування; виникненням комерційної баянноакордеонної індустрії; відкриттям приватних баянно-акордеонних шкіл при студіях звукозапису; запровадженням професійних форм музикування у практику баяністівакордеоністів за рахунок освічених музикантів, які в другій половині XX століття все частіше реалізовують творчі амбіції в галузі естрадного мистецтва.

Визначення й аналіз типів (народно-національний, самодіяльний, масовий, естрадний) сербської баянно-акордеонної школи дозволив дійти висновку, що сербська баянноакордеонна школа народної музики є руховим явищем, яка трансформується під впливом 
соціокультурних тенденцій локальної країни, але незмінна залишається ії традиційна музична основа; процес трансформації баянно-акордеонної школи народної музики відбувався так: від аматорського музикування через синкретичне виконавське мистецтво до організованих музично-освітніх форм баянно-акордеонної практики.

Академічний тип сербської баянно-акордеонної школи виник у 1960-х роках ХХ століття на базі народної баянно-акордеонної практики баяністів-акордеоністів та пов'язаний 3 уведенням спеціальності «Баян-акордеон» до системи державної початкової музичної освіти. Процес академізації сербської баянно-акордеонної школи визначено в такій послідовності: від народної музики через дестабілізувальний синкретизм суспільного мислення до уніфікації (академізації) баянно-акордеонного виконавства.

Установлено, що в межах академічного типу сербської баянно-акордеонної школи склалися форми організації навчально-виховного процесу та педагогічні принципи підготовки баяністів-акордеоністів, які суттєво вирізняються від підготовки в баянноакордеонних школах народної музики, а саме: обов'язкове оцінювання успішності учнів; надання атестата державного зразка; установлений термін навчання; обов'язковий розподіл за класами та групами; єдині програмні вимоги; індивідуальна форма навчання; систематичність і послідовність; поглиблене вивчення теорії та історії музики, опанування творів різних стилів і жанрів.

Порівняльний аналіз двох музично-освітніх напрямів дозволив дійти висновку, що академічний тип сербської баянно-акордеонної школи, на відміну від її народного типу, має універсальний міжнародний статус та розвивається під впливом культуроосвітніх національних і світових тенденцій.

У системі сучасної баянно-акордеонної освіти стверджується академічно-народний mun школи, у якому співіснують два напрями підготовки баяністів-акордеоністів - народний i професійний. На основі аналізу освітніх технологій та організації навчально-виховного процесу сербської баянно-акордеонної школи визначено її характерні риси:

- неподільність початкової та середньої ланок системи музичної освіти;

- зарахування баяністів-акордеоністів до початкової музичної школи на конкурсній основі;

- відсутність регламентованої академічної звітності у процесі навчання;

- підготовка фахівців у галузі баянно-акордеонної справи локально-національного призначення (за народним напрямом) та універсального статусу (за академічним напрямом).

Уведення народного напряму до системи академічної баянно-акордеонної освіти дозволило музично-освітнім установам вирішувати кілька завдань: установити зв'язок між народним та професійним напрямами галузі; розширити компетенції баяністів-акордеоністів; наповнити професійним змістом підготовку музикантів за народним спрямуванням; надати можливість баяністам-акордеоністам за народним напрямом продовжити навчання на рівнях середньої та вищої музичної освіти; збільшити контингент баяністів-акордеоністів у державних музичних закладах.

Особливу роль у процесі підготовки баяністів-акордеоністів широкого профілю в умовах баянно-акордеонних шкіл академічно-народного типу відіграє художньо-естетичне виховання у класі спеціального інструмента. Головним інструментом розвитку художньоестетичних якостей у баяністів-акордеоністів у класі індивідуальних занять є процес роботи над музичним репертуаром, у межах якого формується художньо-образне мислення, логіка «розкодування» музичних знаків, здійснюється вибір оптимального виконавського варіанта, 
розв'язуються технічні завдання, що зумовлено першорядною місією виконавця відтворення художньо-естетичного змісту музики. Репертуарний арсенал сербських баяністів-акордеоністів складається 3 академічних творів та традиційної музики в рівних пропорціях, що забезпечує баяністам-акордеоністам подальшу професійну реалізацію в різних сферах (культурно-розважальній, музично-педагогічній, виконавській) діяльності. Отже, у процесі вивчення закономірностей теорії еволюції стає очевидним, що баянноакордеонна школа, яку ми розглядаємо за жанровою класифікацією, виникла в надрах народної музики і внаслідок диференціації художнього мислення (за В. Варламовим, десинкретизації художньої творчості [2, с. 88]), утворився самостійний тип академічної творчої діяльності, що цілком збігається із запропонованою нами типологією. Ознаки академізації (десинкретизації) спостерігаємо в передуванні синкретизму до диференційованого (дестабілізуючого синкретизму) мислення, унаслідок якого поглиблюється антропологічно-соціальні відносини, інтонаційна музична мова здобуває універсальний статус.

Якщо спробувати визначити процесуальну сутність академізації сербської баянноакордеонної школи, то, на нашу думку, це може мати такий вигляд: від народної музики та ї̈ синкретичних форм через дестабілізуючий синкретизм суспільного мислення, художньої творчості та уніфікації (академізачії) музично-мовної інтонації до універсального (глобального) мистеитва майбутнього. Педагогічний компонент у цьому сенсі розглядаємо як невід'ємний складник процесуального акту, оскільки виконавська школа, що вчить мистецтву гри на інструменті, підпорядкована історичній сутності музичної культури, та як науково-практична установа академічного типу здатна до узагальнення еволюційних музичних процесів, інтеграції національної освітньої системи до музичного універсального міжнаціонального простору, упровадження інноваційних технологій, одночасно зберігаючи етнічно-національну унікальність школи народного баянізму.

Відмінні риси двох полярних типів народного/професійного, які виникли в різні історичні періоди та підпорядковані двом системам музичного мислення, спостерігаємо у творчих методах і художніх жанрах як посередниках цього мислення у відповідних мовноінтонаційних полюсах різних епох: народна музична школа зберігає традиції синкретизму множинності видів моностилістики [5], академічна школа розглядається як універсальна багатожанрова установа.

Отже, аналіз структури сербської баянно-акордеонної школи як системи дозволив визначити іiі типи за напрямами: народні: народно-національний, самодіяльний, масовий, естрадний; професійні: академічний, академічно-народний, які вирізняються: рівнем фахової компетентності педагогів, організацією навчально-виховного процесу, соціальним статусом, формами власності, напрямами підготовки баяністів-акордеоністів, музичним репертуаром. В основу запропонованої типології покладено систему музичних жанрів О. Соколова, що базується на класифікації музичних явищ за такими ознаками: сфера побутування, соціальний статус, період поширення, види та напрями музичної діяльності, які стали критеріями типологізації сербської баянно-акордеонної школи.

Аналіз типів сербської баянно-акордеонної школи дозволив дослідити процес іiі академізації, який розглядаємо в три етапи: перший - асиміляція культуроосвітніх традицій упровадження в систему баянно-акордеонної підготовки музично-педагогічного досвіду шкіл-партнерів; другий - закономірний - відбувається у процесі еволюції суспільного мислення, музично-інтонаційної мови та художньо-виражальних засобів баянноакордеонного виконавства; третій - синкретичний - розглянуто у взаємозалежності i 
співіснуванні народної та академічної практики підготовки баяністів-акордеоністів у системі музичної освіти.

Перспективи подальших наукових розвідок убачаємо в подальшому дослідженні типів сербської баянно-акордеонної школи в контексті єдиної музично-освітньої національної системи зазначеної країни.

\section{Література}

1. Альшванг А. Людвиг ван Бетховен: очерк жизни и творчества / А. Альшванг. Москва : Музыка, 1966. - 630 с. 2. Варламов Д. Народное в музыкально-инструментальном искусстве / Д. Варламов. - Саратов : Издательский центр «Наука», 2007. - 164 с. 3. Соколов О. Морфологическая система музыки и еe художественные жанры / О. Соколов. - Нижний Новгород : Изд-во Нижегородского университета, 1994. - 215 с. 4. Сохор А. Эстетическая природа жанра в музыке / А. Сохор. - Москва : Музыка, 1968. 105 с. 5. Суббота О. В. Музична моторність як категорія музикознавства: дис. ... канд. мистецтвознавства: 17.00 .03 / О. В. Суббота. - Одеса, 2005. - 197 с. 6. Besseler Н. Spielfiguren in der Instrumentalmusik / Besseler H. Jahrbuch, Leipzig, 1956. - P. 13-58.

УДК 37.017.7:373.9

Світлана Федоренко

\section{НАВЧАЛЬНІ КУРСИ-СЕМІНАРИ ДЛЯ СТУДЕНТІВ ПЕРШОГО РОКУ НАВЧАННЯ В СИСТЕМІ ЗАГАЛЬНОЇ ГУМАНІТАРНОЇ ПІДГОТОВКИ У ВИЩІЙ ШКОЛІ США}

Федоренко С. В. Навчальні курси-семінари для студентів першого року начання в системі загальної гуманітарної підготовки у вищій школі США.

У статті висвітлено особливості навчальних курсів-семінарів у системі загальної гуманітарної підготовки у вищій школі США, які спрямовані на використання комунікації як ефективного інструментарію формування гуманітарної культури студентів. Розглянуто створення динамічної взаємодії між викладачами та студентами, де ідеї і знання передаються й обговорюються в критично-заохочувальній манері, що перетворює студентів на активних учасників власного навчання і виховання.

Ключові слова: гуманітарна культура студентів, комунікативні навички, вища освіта США, загальна гуманітарна підготовка, навчальні курси-семінари, студенти бакалавріату.

Федоренко С. В. Учебные курсы-семинары для студентов первого года обучения в системе общей гуманитарной подготовки в высшей школе США.

В статье освещены особенности учебных курсов-семинаров в системе общей гуманитарной подготовки в высшей школе США, направленные на использование коммуникации как эффективного инструментария формирования гуманитарной культуры студентов. Рассмотрено создание динамического взаимодействия между преподавателями и студентами, где идеи и знания передаются и обсуждаются в критически-поощрительной манере, превращая студентов в активных участников собственного обучения и воспитания.

Ключевые слова: гуманитарная культура студентов, коммуникативные навыки, высшее образование США, общая гуманитарная подготовка, учебные курсы-семинары, студенты бакалавриата.

Fedorenko S. V. Training seminars for the first year students in the system of general liberal education at the higher schools of the USA. 